fell again to $102^{\circ}$, and on Tuesday it was normal on both sides. From beginning to end the patient was singularly free from bad symptoms, and made an uninterrupted recovery.

A singular case of unilateral temperature was reported from the Edinburgh Infirmary a few years ago in a bysterical girl, the thermometer registering as high as $110^{\circ}$ in one axilla, while the other showed a normal temperature. The hysterical element was not a factor in this case, however, and it is difficult to account for the freak unless abnormal placidity of temperament has a disturbing effect on our newly discovered friends the thermic centres. The practical lesson, however, is to take the temperature in both axilla and under the tongue in doubtful cases, keeping in view the possibility of variation.

west Norwood.

\section{CASE OF PUERPERAL ECLAMPSIA TREATED WITH ANTIPYRIN.}

By F. Craddock Palmer, M.D. Brux., M.R.C.S., \&c.

ON Aug. 13th, 1890, I was called to see Mrs. T-, aged twenty-eight, six months and a half pregnant, primipara Her husband told me his wife had always enjoyed good health until a few weeks ago, since which time she had had swelling of face, hands, and legs, and the last day or two had complained of headache and had passed very little urine. On returning home soon after 6 P.M., he found her lying on the floor, partially undressed, quite unconscious, with blood oozing from her mouth. On my arrival, soon after 7 P.M., I found her just recovering from a fit. Her tongue was very much swollen, and had been bitten. She was quite unconscious, pupils widely dilated, pulse 98 , and face and extremities much swollen. On examination I found the os uteri contracted. She had passed about four ounces of urine, which I afterwards examined and found to be almost solid with albumen. Shortly after my arrival she had severe convulsions, and as soon after this as it was possible I put fifteen grains of antipyrin on her tongue, and directed another dose to be given her in four hours' time. On Aug. 14th the nurse told me that the patient had had seven fits during the night, but none since $2.30 \mathrm{~A}$.M., and only one, and that a slight one, since the second powder was given. She had passed urine in the bed. At 10 A.M. she was sleeping quietly, pulse 70 , and when roused I found her to be in a semi-conscious condition. The child was alive. I prescribed purgatives and milk diet. She improved daily, and two days after I prescribed iron. examined her urine on Aug. 24th, and found only a trace of albumen. After this she apparently got well, but on Sept. 23rd I was called to her, as she had had another fit. I saw her before she had regained consciousness, and as soon as I was able gave her fifteen grains of antipyrin. She had no more attacks. I examined her urine and found it contained albumen, but not so much as in the previous attack. She went on well until Oct. 24 th, when she was confined and had a normal labour, excepting that the child was stillborn and had been dead for some time. She made a good recovery after this.

Remarks. - The above case is interesting, as I believe it is rarely one has the opportunity of seeing a recurrence of eclampsia during the same pregnancy. Whether the antipyrin had anything to do with the mitigation of the fits I cannot say, but it certainly reduces blood-pressure quickly, and $I$ cannot find any mention of its having been given in cases of eclampsia before.

Woking.

SOCIETY FOR RELIEF OF WIDOWS AND ORPHANS of MEdical MEN - At a quarterly court of the directors of this Society, held on Wednesday, Oct. 14tb, the Piesident (Sir James Paget) in the chair, it was resolved to distribute $£ 1420$ at the next court to the sixty-four widows and twenty orphans applying for assistance. Fresh applications were read from two widows and six orphans, and relief was given them. The expenses of the quarter were $\mathfrak{1 6 3} 14 s .6 d$. A legacy of $£ 20$ from a deceased member was announced. One new member was elected, and the deaths of six reported by the secretary, as well as the death of a widow who had been receiving $f 50$ per annum since June, 1873 .

\section{A}

OP

\section{HOSPITAL PRACTICE,}

\author{
BRITISH AND FOREIGN.
}

Nulla autem est alia pro certo noscendi via, nisi quamplurimas et mor borum et díssectionum historias, tum aliorum tum proprias collecta habere, et inter se comparare.-MORGagNI De Sed. et Caus, Morb. lib. iv. Procemium.

\section{ST. THOMAS'S HOSPITAL.}

CONCUSSION OF THE SPINAL CORD; RECOVERY; REMARKS,

(Under the care of Mr. ClUTtoN.)

THE account of this case is a useful contribution to the literature on spinal injuries, forming another link in the chain of evidence in favour of the occurrence of concussion of the spinal cord independently of discoverable lesion of the canal in which it is placed. Mr. Page ${ }^{1}$ writes: "There is scanty proof of the liability of the spinal cord to suffer from concussion pure and simple in the absence of simultaneous injury to the spinal column, the ex. ceptional cases being extremely rare." Professor Erb, in writing on the subject of spinal concussion, says: "Slight changes, small capillary extravasations, \&c., probably exist in such cases, but they do not seem to constitute the proper essence of the disease; for the most part the anatomical change is quite negative, and we do not know yet what changes, if any, constitute the basis of the concussion proper. The most common view, therefore, is that which supposes only molecular changes in the finer nerve elements to have occurred, giving rise either to an immediate and complete functional paralysis of the latter, or forming the commencement of further disturbances of nutrition, which at a later time may result in degenerative inflammation. The first thing consists in collecting accurate reports of cases." The points in this case to which special attention is directed are the absence of insensibility, the immediate appearance of an extensive and complete paralysis of motion, the comparatively rapid recovery of power, and the absence of later symptoms. For most of the following notes we are indebted to Mr. E. C. Stabb, surgical registrar.

C. S-, a labourer, aged sixty-seven, was admitted on March 18th, 1891. Fifteen hours before admission, on re turning home at night the worse for liquor, he fell down a flight of stairs. He remembered the fall, but could not say how it happened. He did not lose consciousness, but found that he could not move his legs, and remained in the same position till the next morning.

On admission he was a healthy-looking man, complaining of slight pain in the cervical region of the spine, and loss of power in the legs. On examining the spinal column, nothing was discovered. There was no tenderness, no irregularity, and no bruising, but he pointed to the lower cervical spines with his hand to show where he felt pain. Manipulation and preseure at that spot and on the head did not seem to hurt him. He could move his head and spine in any desired direction without pain. There was a small hæmatoma on the vertex. Both legs were completely paralysed, but a few muscles in the upper part of both thighs could be seen to act slightly when he tried to raise his legs. They produced, however, no visible effect on the position of the limbs. Sensation over the legs, thighs, and trunk was normal, or possibly very slightly impaired. The superficial reflexes, such as the plantar and cremasteric, were absent, but the knee jerks were present, and brisk. His mental condition was perfect, and the upper extremities were in no way affected. Respiration was entirely diaphragmatic, the lower sibs being drawn in at each inspiration. His bowels had acted involuntarily, and he had retention of urine. Temperature $998^{\circ}$. Mr. Clutton examined him most carefully, and could find no evidence of any local injury to the spinal column.

March 19th (day after admission).-He conld nove his legs slightly, but the intercostals were still paralysed, and he had retention of urine. Evening temperature $102.4^{\circ}$. Reflexes normal.

1 Injuries of the Spine, p. 74 2 Ziemssen's Cyclopædia of Miedicine 